\title{
The Strategy in Developing International Baccalaureate (IB) High Level Thinking Abilities in Primary School Mathematics Learning (PYP)
}

\author{
Flora Astyna Puri Tarigan* Edy Surya Edi Syahputra \\ State University of Medan, Jl. Willem Iskandar Psr. V Medan, Indonesia
}

\begin{abstract}
This study aims to improve the learning process and develop high-level thinking skills of students through the learning process using the International baccalaureate curriculum in $5^{\text {th }}$ grade students at Siti Hajar Islamic Elementary School. This research is classroom action research (PTK) and carried out in three cycles, where each cycle consists of planning, action, observation and reflection. The aspects observed in each cycle are the activities of students and teachers, as well as the process of learning mathematics in class. The research subjects were 48 students consisting of 24 male students and 24 female students. The analysis of research on students' high-level thinking skills in mathematics learning using the Solo Taxonomy assessment which consists of 4 levels of high-level thinking, namely: (Unstructured, Multi-structural, Relational, and Extended Abstract). From the results of cycle 1, the percentage of students who reached the extended abstract level was $13.33 \%$, in the second cycle, the level of thinking of students at the extended abstract level was $67.53 \%$ and in the third cycle the percentage of students who reached the level of extended abstract thinking was 77.33. Based on the indicators of success in the third cycle, the learning process of using the International baccalaureate curriculum in $5^{\text {th }}$ grade students at Siti Hajar Islamic Elementary School has proven to improve students' high-level thinking skills in mathematics learning.
\end{abstract}

Keywords: International Baccalaureate Curriculum, HOTS, Solo Taxonomy

DOI: $10.7176 / \mathrm{JEP} / 10-33-07$

Publication date: November $30^{\text {th }} 2019$

\section{INTRODUCTION}

Studying high level thinking ability in mathematics learning at the elementary school level becomes the most important part in answering the global challenges of the 21 st century. Students in the 21 st century are expected to become professionals and possess a global character and international mindset. International Baccalaureate Organization (2019) has been believed to be alternative in order to solve problems in everyday life. Thus, using thinking skills through mathematics learning strategies in the classroom will support students to be broadminded and have high-level thinking skills (Tanujaya, Mumu \& Margono, 2017). In the African Education Festival organized by the International Baccalaureate Organization (IBO, 2019), Hughes (as citen in Wootten, 2019) said that teachers in Africa have worked on preparing programs that can answer all 21st century challenges. Their main goal is to prepare students who have critical and creative thinking skills as well as become broad-minded. Broad mindedness or possibly implying an open global understanding or mindedness is the vision and mission of the International Baccalaureate (IB) which is to assist young students to think broadly and realize the importance of preserving nature and planet Earth as a safe place to live and create a more peaceful world condition. This is described through ten International Baccalaureate profiles which will be discussed in later part. This has also been clearly mentioned in the initial aim of IB which is to develop people to be internationally minded and to nurture the capability of people in recognizing their mutual humanity and leadership. In the long run, the students are expected to create a better and more peaceful world.

From the statement above, it is obvious that in order to realize the vision and mission of the International baccalaureate (IB), IB prepares students to be human beings who are able to think internationally as well as being broad-minded students. The aims are to develop high-level thinking skills and to be able to solve problems in their daily lives. The aim of learning mathematics at the elementary school level is to create students who are able to solve everyday problems using mathematical concepts. In fact, the learning strategies in the 2013 curriculum in Indonesia have not been able to guide teachers to teach and test their students how to think in high order. The strategies used by the teacher during the learning process are possibly far more important, than just giving a test to measure high-level thinking skills (Collin, 2017). But, from what have been reported by the Organization of Economic Co-Operation and Development (OECD) on the Programme for International Student Assessment, Indonesia ranked $64^{\text {th }}$ out of 65 other countries in 2012.

To develop high-level thinking skills, especially critical thinking, there are 5 ways or strategies that can be used by the teacher during learning, namely; 1) Regulate the learning objectives, 2) inquiry teaching based, 3) Practice, 4) Periodic review, refine and develop understanding, and 5) Run through feedback and assess learning. (Kusuma, Rosidin, Abdurrahman, Suyatna 2017; Limbach and Waugh, 2010). Therefore the strategy of 
developing students' high-level thinking skills can be improved through an inquiry-based mathematics learning process and providing feedback after the learning process. This is what underlies that the International Baccalaureate (IB) curriculum which aims are to help students think in high order particularly in association with its ten IB profiles, namely: Reflective, Open-minded, Risk-taker, Caring, Balance, Knowledgeable, Inquirer, Communicator, Thinker and Principle.

\section{LITERATURE REVIEW}

\subsection{High Order Thinking Skill (Bloom Taxonomy / Solo Taxonomy)}

Speaking about the definition of High Order Thinking Skill (HOTS) Brookhart (2010) identifies that the definition of high thinking ability (HOTS) is divided into 3 categories of defining terms, namely: (1) Transfer, (2) Critical Thinking, (3) Problem Solving. From these 3 categories, Collin (2017) defines that, high-level thinking skills are said to be in transfer institutions, where students have knowledge and skills but must also be able to apply these knowledge and skills to new situations in their lives. In the second category, the critical thinking is that it is able to think, it means that students can apply wise decisions or produce a reasoned critique. This means that the learning objectives in the classroom must be able to direct students to be more prudent in determining the right decisions and train students to learn as well as to give an assessment. To define the third category term, Collin (2017) defines that high-level thinking ultimate skill is also problem solving which ability that does not provide an opportunity for someone to find solutions to problems by the skill of memorization. Finding a solution to the problem needs the ability to analyze problems and logic algorithms that require a high level of thinking process. Bransford and Stein (1984) point out the significant role of problem solving as general mechanism behind thinking, including recall, critical thinking, creative thinking and effective communication. Based on some of the definitions above, the ability to think at a high order is the ability that requires someone not only to have a lot of knowledge but to be able to apply that knowledge in any situation and be able to make decisions and assess things and be able to find solutions to problems in various ways.

\subsection{International Baccalaureate Curriculum}

\subsubsection{International Mindedness (International Insight)}

International insight is very imperative for the IB mission and is a rudimentary principle of the IB's educational philosophy; this is at the fundamental of the international education continuum. International insight is an understanding of the world where people see themselves connected with the global community and carry wisdom of responsibility towards its members. This is a cognizance of the relationship between all nations and people, and is an acknowledgment of its complexity (IBO, 2019). Internationally-minded people respect the diversity of society, culture and the social order in the world. They strive to learn more about others and develop empathy and solidarity with others in order to achieve mutual understanding and respect. To become an international-minded student, schools that use the International Baccalaureate curriculum provide standards and profiles that students must demonstrate namely Reflective, Open-minded, Risk-taker, Caring, Balance, Knowledgeable, Inquirer, Communicator, Thinker and Principle (IBO, 2017)

\subsubsection{International Baccalaureate Profile (IB Profile)}

The International Baccalaureate Profile is an identity that is part of the vision and mission of the international education curriculum that supports students becoming international-minded students. The 10 profiles of International Baccalaureate students are:

1. Inquirer: Students develop curiosity, by developing inquiry and research skills. Understand how to learn independently or in teamwork. Students also learn with enthusiasm and maintain their love for lifelong learning.

2. Knowledge (Knowledgeable): Students develop and use conceptual understanding, by exploring knowledge in various cross-disciplinary disciplines. Students are involved in problems and ideas that have significant meaning locally and globally.

3. Thinker (Thinker): Students use critical and creative thinking skills to analyze and take actions that are responsible for complex problems. Students are trained for initiative in making ethical and reasonable decisions

4. Communicator (Communicator): Students express themselves with confidence and creativity in more than one language and in many ways. Students need to collaborate effectively, by listening carefully to the perspectives of other people or groups

5. Principles: Students act with a sense of integrity and honesty, with a sense of equality and justice, and with great respect for the dignity and rights of people everywhere. Students are responsible for their own actions and with all the consequences.

6. Open-minded: Students really value their own culture and history, but also appreciate the values and traditions of others. Students seek and evaluate a variety of perspectives, and are willing to grow based on that experience. 
7. Caring: Students show empathy, compassion, and respect. They are committed to serving, and students act to produce positive changes in the lives of others and in the environment around them.

8. Balanced: Students understand the importance of balancing various aspects of their different lives intellectual, physical and emotional - to achieve the well-being of others and themselves. Students recognize the nature of their interdependence with others and the world in which they live.

9. Dare to Take Risks (Risk-Taker): Students handle an unreliable situation with full anticipation beforehand and with determination; they must be able to work independently and cooperatively to travel around new ideas and to discover innovative approaches. They also need to be creative and resilient in facing challenges and changes.

10. Reflective (Reflective): Students carefully consider their own world, thoughts and experiences. They strive to understand their strengths and weaknesses and to maintain the development of their learning and progress.

\subsubsection{International Baccalaureate Approach to Learning Skills (IB ATL)}

Approach to Learning (ATL Skill) is a collection of several skills that are used during learning that must be owned by IB students. ATL Skills on the IB curriculum were compiled the first time by Lance King. The following is a breakdown of skills that IB students must demonstrate during the process of learning taking place, one of which is thinking skills (Thinking Skill) divided into several sub, namely

Thinking Skill:

1. Critical Thinking (Analyzing and evaluating issues and ideas, and forming decisions),

2. Creative Thinking (Generating novel ideas and considering a new perspective),

3. Information Transfer (using skill and knowledgeable in multiple contexts),

4. Reflection and Metacognition (using thinking skills to reflect on learning on the process of learning).

The ATL Skill applied to the IB curriculum is a strategy and development carried out by schools that use the IB curriculum to improve their students' high-level thinking skills.

\subsection{Mathematics Learning System on IB}

Mathematics is regarded as an instrument to support inquiry particularly in the Primary Year Program, given that a global language through which people makes sense of the world around them. The main intention is also to train student in order to become proficient users of language and mathematics. This capability is also seen as a way of thinking where students are asked to do more than just memorizing a series of formulation and equations. The power of mathematics for describing and analyzing the world around us is that it has a highly effective tool for solving problems. The IB learner profile is the most effective way to learn about it as well as the learner profile, together with the other elements of the program - knowledge, concepts, skills and action - informs planning and teaching in mathematics. The mathematics component of the curriculum of Primary Years Programme (PYP) encompasses measurement, shape and number, and their many applications to students' everyday lives. Mathematics provides opportunities for students to study into measurement, shape and number, and allows them to communicate in a language that is concise and unambiguous. Mathematics concepts and skills can also be applied to a variety of real-life problems. Students apply their mathematical reasoning to a number of situations in order to find the right answer to the problems they wish to solve.

\subsection{Strategies Used by IBs to Support Mathematics Learning Curricula and HOTS}

There are five lessons suggested in order to develop the ability to critical thinking critically, namely: (1) regulate the learning purposes, (2) inquiry teaching based, (3) practice, (4) periodical review, upgrade and improve understanding, and (5) run through feedback and assess learning (Limbach \& Waugh, 2010; Kusuma \& et al. 2017). From the statement above one way to develop high-level thinking skills or HOTS in students is by teaching through inquiry or if it is possible, a realistic context of the units of inquiry. The direct teaching of mathematics in a unit of inquiry may not always be feasible but where appropriate, introductory or follow-up activities may be useful. Students also need opportunities to identify and reflect on ideas that are between different strands of mathematics, the program of inquiry and other subjects.

\subsection{The Assessment Standard}

The standard of assessment carried out in schools that use the IB curriculum on the application of documents into principle is the standard assessment of solo taxonomy. This structure of observed learning outcomes or popularly known as SOLO is an ideal model that designates the levels of increasing difficulty in students' understanding of subjects. It was proposed by John B. Biggs and Kevin F. Collis (Hook \& Mills, 2012). 


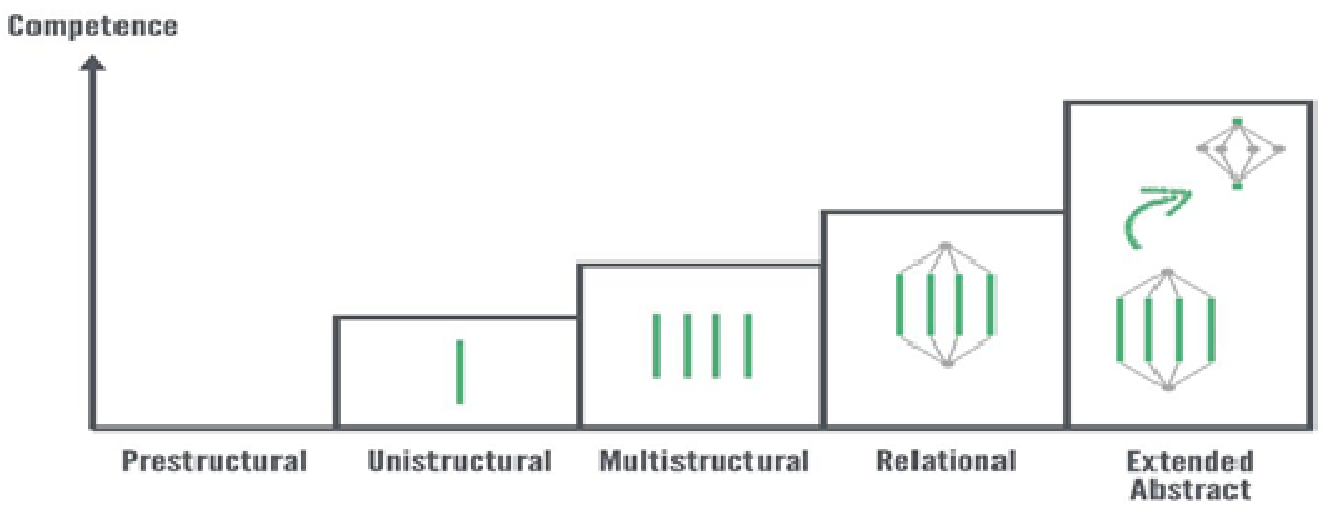

Figure 1. Level of understanding of students in Solo Taxonomy

Correlating the levels in SOLO with "declarative knowledge verbs" in the process of "constructive alignment" (Biggs and Tang 2007) is essential to building clarity, competence and confidence into the process of writing intention (Hook \& Mills, 2012). In New Zealand Solo Taxonomy Verb list signifying the student has achieved a high order thinking skills particularly at the level of relational and extended abstract. Students are said to be able to think in high order if they can communicate ideas or knowledge through the Solo Taxonomy Verb. These verbs are categorized as the following;

\begin{tabular}{|l|l|}
\hline Unistructural & $\begin{array}{l}\text { Define, identify, name, draw, find, label, match, follow a } \\
\text { simple procedure }\end{array}$ \\
\hline Multistructural & Describe, list, outline, follow an algorithm, combine \\
\hline Relational & $\begin{array}{l}\text { Sequence, classify, compare and contrast, explain causes, } \\
\text { explain effects, analyses (part-whole), form an analogy, } \\
\text { Organize, distinguish, interview, question, relate, and apply. }\end{array}$ \\
\hline $\begin{array}{l}\text { Extended } \\
\text { Abstract }\end{array}$ & $\begin{array}{l}\text { Generalize, predict, evaluate, reflect, hypothesize, theories, } \\
\text { create, prove, plan, justify, argue, compose, prioritize, design, } \\
\text { Perform. }\end{array}$ \\
\hline
\end{tabular}

Table. 1. Solo declarative and functioning learning verb

The highest standard of assessment is Extended Abstract where students can think at a high order (HOTS) or known as Out of the Box Thinking Skill. The SOLO theory of teaching and learning is based on research during the student learning process where students exceed knowledge level capacity above the level of knowledge of Bloom's Taxonomy (Hook \& Mills, 2012)

\section{RESEARCH METHOD}

The research method used is classroom action research (PTK) conducted in Aljabr Islamic Elementary School, which consists of 2 classes namely 48A and 5A grade students and consists of 24 male and 24 female students. The research instruments used were: IB Planner (International Baccalaureate Learning Plan) student observation sheet, teacher observation sheet and standardized Solo Taxonomy high-level thinking ability test, Student Feedback Learning sheet, student inclusion worksheet, observation videos of learning activities and photos of learning activities. All data obtained is processed and is evidence of the effectiveness of the learning strategies used.

\section{RESULT AND DICUSSION}

The results of research on students' high-level thinking skills in mathematics learning using the Solo Taxonomy assessment which consists of 4 levels of high-level thinking, namely: (Unistructural, Multi-structural, Relational, and Extended Abstract) show some significant outcomes. From the results of cycle 1, the percentage of students who reached the extended abstract level was $13.33 \%$, in the second cycle, the level of thinking of students at the extended abstract level was $67.53 \%$ and in the third cycle the percentage of students who reached the level of extended abstract thinking was 77.33. Based on the indicators of success in the third cycle, the learning process uses the International baccalaureate curriculum in $5^{\text {th }}$ grade students of Siti Hajar Islamic Elementary School has clearly shown how it has improved students' high-level thinking skills in mathematics learning. 


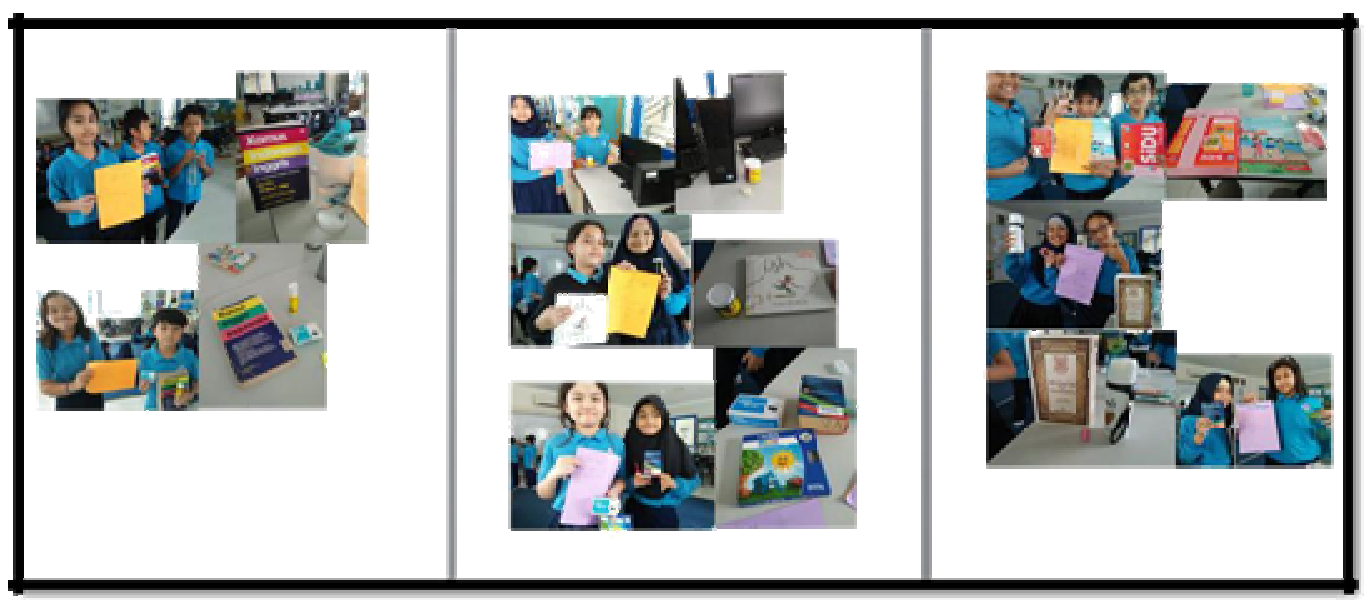

Figure 2. Student used material around them to construct their understanding about measuring volume of 3D shape by inquiry process from IB Curriculum

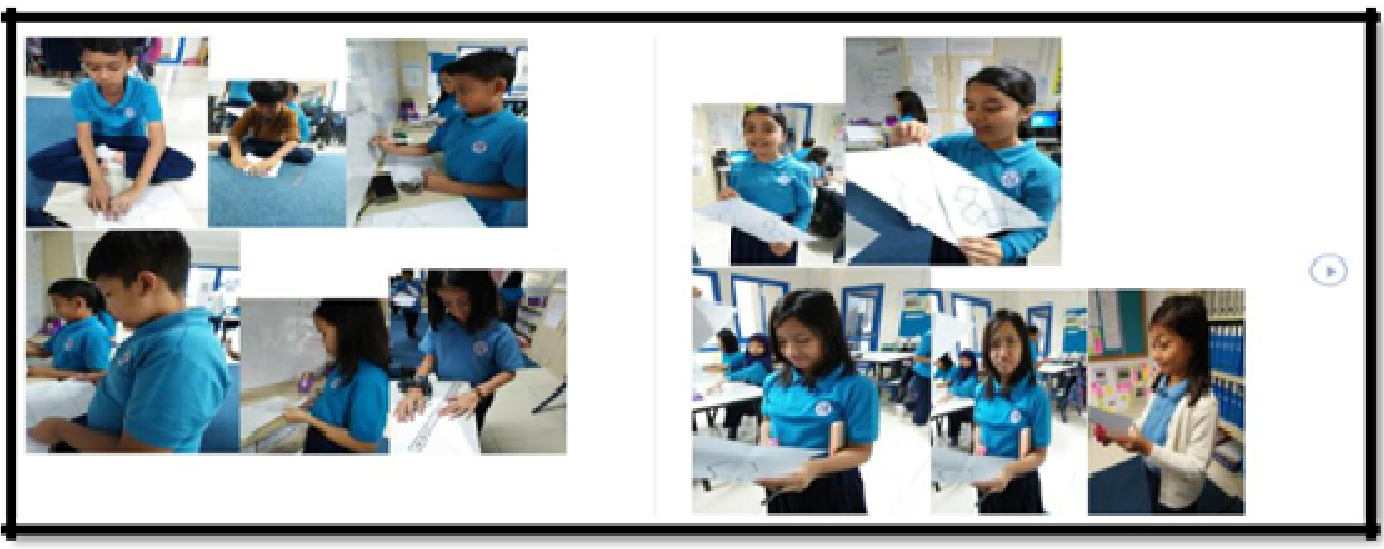

Figure 3. Student used material around them to construct their understanding about measuring volume of 3D shape by inquiry process from IB Curriculum

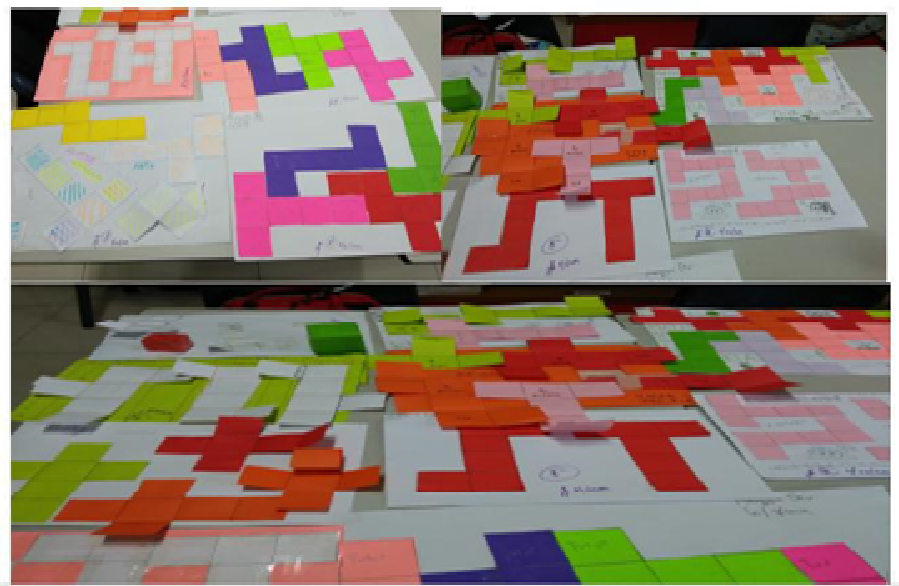

Figure 4. The results of the learning process of students through the process of elimination by creating and designing webs of cubes with the knowledge they have. Students apply creative thinking skills throughout the process.

The success of this study is supported by the results of research conducted by Yen \& Halili (2015) who found that developing high-level thinking skills (HOT) is a tough challenge where there are several factors that must be fulfilled while teaching HOT abilities; this has been aligning to this study as well where some factors play important roles. These factors include: (1) time factor, where it takes a long time to develop high-level thinking skills. (2) Student factors, students must have high motivation to think, (3) teacher factors, many teachers themselves are confused in defining thinking skills, also unsure in teaching HOT abilities. Thus, 
training and preparing teachers on the topic of HOTS is critical (4) Assessment Factors, in which a set of symptoms requires standardization of a test. This failure of making a proper test makes the learning process in the class does not support the maximum implementation of HOT students and only focuses on achieving the results of standard tests given, (5) student learning environment factors, learning environment factors such as classroom equipment, class atmosphere can also support HOT development, learning process can be accustomed to students in order to minimize the level of difficult for students to achieve HOT, (6) learning source factors, supportive learning resources, will enhance the development of high-level thinking skills of students. From the 6 factors above, it is evident that Siti Hajar Islamic Elementary School that uses the IB curriculum is very helpful for teachers in the learning process and the development of high-level thinking abilities (HOT) students. These six factors are the basic standards of implementing the IB curriculum. This is also evidenced by the IB's spread program in its latest document of this current year.

\section{REFERENCES}

Biggs, J., \& Tang, C. (2007). Teaching for quality learning at university Maidenhead. Berkshire, UK: McGrawHill Education.

Bransford, J. D., \& Stein, B. S. (1984). The ideal problem solver. A guide for improving thinking, learning, and creativity. A Series of Books in Psychology, New York: Freeman, 1984.

Collin. R., (2017). Curriculum Leadership Journal. Skill for the $21^{\text {st }}$ Century: Teaching Higher-Order Thinking. Vol 12, No. 14. ISSN: 1448-0743.

Hook, P., \& Mills, J. (2012). SOLO Taxonomy: A Guide for Schools. Planning for Differentiation. Essential Resources.

IBO. (2017). Making Primary Years Programe (PYP) Happens. International baccalaureate Organization. New Zealand

IBO (2019). Principle Into Practice. International baccalaureate Organization. New Zealand

Kusuma, M. D., \& Rosidin, U. Abdurrahman and Suyatna A (2017). The development of higher order thinking skill (HOTS) instrument assessment in physics study. IOSR Journal of Research \& Method in Education (IOSR-JRME), 7(1), 26-32..

Limbach, B., \& Waugh, W. (2010). Developing Higher Level Thinking. Journal of Instructional Pedagogies, 3.

Tanujaya, B., Mumu, J., \& Margono, G. (2017). The Relationship between Higher Order Thinking Skills and Academic Performance of Student in Mathematics Instruction. International Education Studies, 10(11), 7885.

Wootten, L. M. (2019). Exploring 21 st Century Teaching and LearningSkills in the International Baccalaureate Continuum Training and Practice (Doctoral dissertation, Northcentral University).

Yen, T. S., \& Halili, S. H. (2015). Effective teaching of higher order thinking (HOT) in education. The Online Journal of Distance Education and e-Learning, 3(2), 41-47. 